\title{
BMJ Open Substance use disorders and adherence to antituberculosis medications in Southwest Ethiopia: a prospective cohort study
}

\author{
Matiwos Soboka (1D , ${ }^{1,2}$ Markos Tesfaye, ${ }^{2,3}$ Kristina Adorjan, ${ }^{2,4,5}$ Wolfgang Krahl, ${ }^{2,6}$ \\ Elias Tesfaye, ${ }^{1}$ Yimenu Yitayih (D) , ${ }^{1}$ Ralf Strobl, ${ }^{7,8}$ Eva Grill ${ }^{2,7,8}$
}

To cite: Soboka M, Tesfaye M, Adorjan K, et al. Substance use disorders and adherence to antituberculosis medications in Southwest Ethiopia: a prospective cohort study. BMJ Open 2021;11:e043050. doi:10.1136/ bmjopen-2020-043050

- Prepublication history for this paper is available online. To view these files, please visit the journal online (http://dx.doi. org/10.1136/bmjopen-2020043050).

Received 24 July 2020 Accepted 01 June 2021

Check for updates

(C) Author(s) (or their employer(s)) 2021. Re-use permitted under CC BY-NC. No commercial re-use. See rights and permissions. Published by BMJ.

For numbered affiliations see end of article.

Correspondence to Mr Matiwos Soboka; matiwos2004@yahoo.com

\section{ABSTRACT}

Objectives In Ethiopia, little is known about the association between substance use disorders and adherence to antituberculosis (anti-TB) medications. Therefore, the objective of this study was to assess the effect of substance use disorders on adherence to anti-TB medications in Southwest Ethiopia.

Design Prospective cohort study.

Settings Patients were recruited from 22 health centres and four hospitals in Southwest Ethiopia.

Participants This study was conducted among 268 patients with TB, aged 18-80 in Southwest Ethiopia between October 2017 and October 2018. At baseline, patients who were exposed substance use disorders (134 patients) and unexposed to substance use disorders (134 patients) were recruited. Patients were followed for 6 months, and data were collected on three occasions. Main outcome measure Adherence to anti-TB medications.

Results Patients with substance use disorders had consistently higher prevalence of non-adherence than those without, $16.4 \%$ versus $3.0 \%$ at baseline, $41.7 \%$ versus $14.4 \%$ at 2 -month follow-up and $45.7 \%$ versus $10.8 \%$ at 6 -month follow-up assessments. Patients with khat use disorder were 3.8 times more likely to be nonadherent to anti-TB medications than patients without khat use disorder (Adjusted odds ratio $(\mathrm{aOR})=3.8,95 \% \mathrm{Cl} 1.8$ to 8.0). Patients who had alcohol use disorder (AUD) were also 3.2 times likely to have poor adherence compared with their counterparts (aOR=3.2, 95\% $\mathrm{Cl} 1.6$ to 6.6). In addition, being educated $(\mathrm{aOR}=4.4,95 \% \mathrm{Cl} 1.7$ to 11.3$)$, and being merchant ( $\mathrm{aOR}=6.1,95 \% \mathrm{Cl} 1.2$ to 30.8$)$ were associated with non-adherence to anti-TB medications. Conclusion Khat and AUDs predict greater likelihood of non-adherence to anti-TB medication. This implies the need to integrate the management for substance use disorders into the existing TB treatment services.

\section{INTRODUCTION}

Tuberculosis (TB) is a preventable and treatable disease but it remains one of the major diseases leading to death worldwide. ${ }^{12} \mathrm{WHO}$ estimates that 1.6 million persons died of TB in $2017^{1}$; almost $20 \%$ of them were HIV positive. ${ }^{1}$ The number of patients with TB is
Strengths and limitations of this study

- The strengths of this study are the prospective cohort design, Iongitudinal data collection, including patients from urban and rural health institutions, intensive training for data collectors, multi-centre data collection and use of standardised instruments.

- Due to social desirability, patients might minimise reporting of the amount and frequency of the substances they were using.

- Measuring adherence based on pills count may not reflect the real adherence situation, since patients may not bring all leftover medications during the follow-up.

- Follow-up and data collections have been carried out by health professionals working in the respective tuberculosis (TB) clinic. As a result, their assessment of adherence might be biased.

- Hospitalised patients, patients on retreatment and patients with multidrug-resistant-TB were not included in this study, and this may limit the generalisability of the result for these patients.

estimated at about 10 million with an annual incidence of $6.4 \%$. TB remains the main reason for premature mortality among HIV positive patients. ${ }^{1}$

TB is most prevalent in middleincome and low-income countries. This exerts enormous pressure on societies as TB mainly affects mostly adults in the economically productive age groups. ${ }^{134}$ In fact, $87 \%$ of cases worldwide are from Asia, Africa and the Russian Federation. ${ }^{15}$ TB-related morbidity and mortality also remain high in low-income and middleincome countries. Because these countries have poor nutrition, unfavourable housing conditions and unstable healthcare. ${ }^{1}$ Notably, 117705 new cases were registered in 2017 in Ethiopia, corresponding to an annual incidence of 164 per 100000 habitants. ${ }^{1}$ Ethiopia remains 
one of the top 22 countries having the highest TB mortality with an estimated mortality rate of 24 per 100000 inhabitants in 2017. ${ }^{1}$

Long-term adherence to standardised medication is the key to successful treatment of TB as non-adherence may lead to the emergence of multidrug-resistant TB (MDR-TB), an increasing global health threat. ${ }^{167}$ Non-adherence to anti-TB medication could also lead to a lower treatment success rate, ${ }^{89}$ default and death. ${ }^{10} 11$ Thus, Ethiopia has developed a national TB treatment guideline to ensure adherence through regular appointments and supervised drug administration, and to reduce poor treatment outcomes. ${ }^{12}$

In Ethiopia, the prevalence of non-adherence among patients with $\mathrm{TB}$ has been estimated to range from $10 \%$ in Amhara region to $24 \%$ in Southern Nations and Nationalities of Ethiopia. ${ }^{13}$ To counteract this, the Ethiopian has implemented direct observed treatment (DOT) services in almost all health institutions, ${ }^{12}$ but its impact on medication adherence is unclear and the reasons for non-adherence are still poorly understood.

Among the reasons for non-adherence, substance use disorders have been found to play a dominant role. ${ }^{814-16}$ Substances such as alcohol, tobacco, khat and illicit drugs are commonly used among patients with TB. ${ }^{17-19}$ Patients with $\mathrm{TB}$ are also at risk of increased morbidity, and premature mortality due to substance use disorders. ${ }^{20}$ Because, substance use disorders such as alcohol and tobacco are associated with MDR-TB. ${ }^{21} 22$

Khat is a natural stimulant with over 40 active compounds. Among these, psychoactive alkaloids, cathinone and cathine cause the stimulating effect, and lead to craving and dependency. ${ }^{23-26}$ There is evidence that khat use increases susceptibility to $\mathrm{TB},{ }^{27-31}$ and maybe associated with poor TB treatment outcomes, ${ }^{1432}$ prolonged duration of treatment ${ }^{33}$ and high load of bacteria in patients with TB. ${ }^{34}$ In Yemen, khat use has been shown to be associated with nonadherence to anti-TB medications, ${ }^{35}$ probably because khat disrupts patients' sleep patterns and causes them to miss their appointments. ${ }^{35} 36$ Ethiopia, like Yemen, counts among the few countries where khat use is legal. Khat use disorder may be an important but unrecognised threat to anti-TB medication adherence. Filling the information gaps about the effect of substance use disorders will help to improve TB treatment outcomes and inform decision-makers about the need for an integration of substance use disorder treatment in TB control programmes in the future. Therefore, the objective of this study is to assess the effect of substance use disorders (including khat and alcohol) on adherence to anti-TB medications in Southwest Ethiopia. Specifically, we examined the association of the most frequently used substances, namely khat and/or alcohol, on adherence to guideline compatible TB treatment.

\section{METHODS}

\section{Study area, period and patients}

We conducted a prospective cohort study in Jimma zone and Jimma city special zone. Jimma city special zone is the capital city of Jimma zone and located in the Southwestern part of Ethiopia, $352 \mathrm{~km}$ from Addis Ababa, the capital of the country. The city has a tertiary hospital and a zonal hospital, as well as four functional health centres those currently providing services. Similarly, Jimma Zone has 18 districts and located in the Southwest of Ethiopia. Overall, the zone has more than 3 million inhabitants. During the period of this study, Jimma Zone had 112 health centres and three hospitals. Out of these government's public health facilities, 91 health centres and all hospitals were providing services to patients with TB. In this study, data were collected from a total of 26 health institutions (22 health centres and four hospitals). From Jimma city, we randomly selected two health centres and one hospital. We also randomly selected 20 health centres and three hospitals from the Jimma Zone. Patients were included if they had initiated anti-TB treatment within a month of start of the study at the selected health centres and hospitals between October 2017 and October 2018. Patients were recruited over the first 6 months. Follow-ups were done at the end of 2 and 6 months of treatment.

\section{Study design}

This study is a multicentre prospective cohort study. We did not pair exposed and non-exposed patients by a certain character. Patients recruited to the cohort were interviewed on three occasions, namely, baseline (starting treatment), first follow-up (after 2 months) and second follow-up (at the end of 6 months).

\section{Sample size assumption and sampling procedure}

In Ethiopia and other African countries, we could not find a study done regarding substance use disorders (alcohol, tobacco, cannabis, amphetamine and others) and adherence to anti-TB. So, we were forced to calculate the sample based on the proportion of adherence to anti-TB among khat users patients with TB. The prevalence of non-adherence among patients with $\mathrm{TB}$ who also used khat from previous studies was $62.4 \% .^{35}$ The prevalence of non-adherence among non-khat user patients with TB was $43.6 \% .{ }^{35}$ We have included 111 exposed (with substance use) and 111 unexposed (without substance use) individuals to detect a difference of non-adherence to anti-TB medication at an alpha level of 0.05 and with a power of $80 \%$ using the corrected Fleiss sample size calculation (EPInfo). ${ }^{37}$ The total sample size was calculated considering a $20 \%$ of drop out rate and the final sample size was 134 in each group which totals 268 patients with TB. New patients with TB who were 18 years or older were recruited to participate in the study. Patients who had been on treatment for more than 1 month, patients on retreatment, and MDR-TB cases were not included in the study. 


\section{Instruments}

Exposure variables

In this study, the exposure variable is substance use disorder which includes khat and/or alcohol use disorder (AUD).

\section{Substance use disorder}

In this study substance use disorder was defined as having khat and/or AUD. Data on tobacco, shisha and cannabis use were collected for explorative data analysis.

\section{Alcohol use disorders}

AUD identification test (AUDIT) was used to collect data on AUDs. ${ }^{38}$ The AUDIT was evaluated over a period of two decades, and provides an accurate measure of risk of AUDs across gender, age and cultures. With a cut-off score of 8 or more, the sensitivity, and specificity of AUDIT for AUDs was 0.90 and 0.80, respectively. ${ }^{39}$ AUDIT was used in Ethiopian context and questions number two and three regarding standard drinks were adapted to a more locally appropriate question. ${ }^{40}$

\section{Nicotine dependence}

The Fagerstrom test for nicotine dependence (FTND) was used to assess tobacco dependence. A total score of FTND $\geq 5$ was considered as tobacco dependence. ${ }^{41}$ At a cut-off score $\geq 5$, the FTND has good sensitivity (0.75), and specificity $(0.80)$. The FTND has six items, with a total score ranging from 0 to 10 to measure nicotine dependence. A total FTND score of 5 indicates moderate nicotine dependence, a score of 6-7 indicates high nicotine dependence and a score of 8-10 indicates very high nicotine dependence. Patients were also asked about their reasons for smoking tobacco. ${ }^{41}$

\section{Cannabis and shisha use}

Use of both substances and their frequency were assessed.

\section{Khat use}

Khat use was assessed by self-reported questionnaire. Since there is no standardised questionnaire for khat use, patterns and reasons of khat use were assessed by using a structured questionnaire which was developed in the context of a literature review. Any consumption of khat in the last 1 month was considered as current khat use.

In this study, frequent khat use (using khat daily and 2-3 times per week) and using more than one bundle of khat per day was considered as khat use disorder. The term 'khat use disorder' is also supported by previous study. $^{42}$

\section{Outcome variable}

Adherence

Adherence status of patients with TB was assessed by DOT (based on missing appointments) and pills counts. In this study, adherence is defined as taking medication regularly and attending follow-up according to appointments and national guideline for TB in Ethiopia. ${ }^{12}$ In this study, non-adherence is defined as missing at least one follow-up appointment during DOT. Non-adherence during intensive phase is defined as missing at least one dose of the prescribed anti-TB medication and noted separately. Adherence was assessed at baseline (beginning of intensive phase), at second month (end of intensive phase) and at end of sixth month (end of continuation phase).

\section{Explanatory variables}

Socio-demographic characterestic

Age, sex, marital status, level of education, religion, ethnicity, income, household size, occupation, place of residence and living conditions were assessed using a structured questionnaire. Income was categorised considering that the minimum monthly wage for employees of governmental organisation in Ethiopia of 1214 Ethiopian birr (€36.67). ${ }^{43}$ Then the monthly income of each patient was multiplied by 12 months to obtain the annual income, and we used a cut-off 14568 Ethiopian birr (€439.98).

\section{Disease related factors}

Types of TB diagnosis (smear positive, smear negative, extrapulmonary TB and MDR-TB) were collected from patients' charts.

\section{Comorbidities}

All confirmed diagnoses of HIV, previous mental illness, hypertension and diabetes mellitus were collected from patients' charts.

\section{Social support}

Oslo Social Support Scale (The Oslo 3-items) was used to collect data on the strength of social support. The Oslo-3 total score 3-8 indicate poor social support, 9-11 indicate moderate social support and 12-14 indicate strong social support. ${ }^{44}$ The scale had been validated in Ethiopia among patients with TB. ${ }^{45}$ Social support was assessed at baseline, second month (at first follow-up) and sixth month (at the completion of anti-TB treatment or second follow-up).

\section{Food insecurity}

It was assessed using the Household Food Insecurity Access Scale (HFIAS) to determine whether the respondent has experienced any of the indicators of food insecurity in the previous month. Food secure if none of the items were endorsed on HFIAS, mild food insecurity if the respondent endorsed any of the items 1, 2, 3 and/or 4 but not the items 5-9, 'moderate food insecurity' if the respondent has endorsed items 5, and/or 6 but not the items 7-9, and 'severe food insecurity' if the respondent has endorsed items 7, 8 and/or 9. ${ }^{46}$ This tool had been validated in Ethiopia among people living with HIV. ${ }^{47}$ Food insecurity assessed at baseline, second month (at first follow-up) and sixth month (at the completion of anti-TB treatment or second follow-up).

\section{Data collection procedures}

Before starting data collection, the questionnaires were pretested on a sample ( $5 \%$ of the total sample) of patients 
with TB who were on treatment at Agaro health centre. Those patients who participated in the pretest were not included in the main cohort study. Data were collected by trained health professionals working in the respective TB clinics. Data collectors were not blind to exposure status of the patients. Also, district TB focal persons and other health professionals specifically trained for this purpose participated in the supervision of data collection.

\section{Data analysis}

Data were entered to Epi Data (V.3.1) and analysed using $\mathrm{R}$ studio (V.1.2.1335). Missing values of income were excluded from the analysis. Participants' characteristics and study variables were presented using descriptive statistics. Generalised linear model was used to examine the longitudinal effect of khat and AUDs on medication adherence (binary outcome). We used an intercept only model to investigate the trajectory of adherence over time (model 0 ). Model 1 investigated the longitudinal effect of presence or absence of khat and AUDs on adherence without adjusting for covariates, model 2 investigated the longitudinal effect of khat and alcohol on adherence while adjusting for the full set of covariates. Model fit was examined with the Bayesian information criterion (BIC).

The covariate selection was based on a directed acyclic graph (DAG). DAGs are analytical method for visualising hypotheses about causal relationships between exposure (substance use disorders) and outcome (adherence). ${ }^{49} 50$ This approach has been shown to yield valid adjustment sets of variables and to avoid bias. ${ }^{51}$

\section{Patient and public involvement}

Patients were not involved in development of the research questions, study design, interpretation of results or writing of the manuscript.

\section{RESULTS}

\section{Sociodemographic characteristics}

A total of 268 newly diagnosed patients $(50 \%$ with substance use disorders, mean age 32.4, SD 14.4, $60.1 \%$ men) with $\mathrm{TB}$ were recruited. There was no loss to follow-up.

Of all patients, $10.8 \%(\mathrm{n}=29)$, and $39.2 \%(\mathrm{n}=105)$ had alcohol and khat use disorders, respectively. No participant had tobacco, shisha or cannabis use disorders. Age range was $18-80$ years with $35 \%$ under 25 years (refer to table 1). There were 22 missing data of annual income which we excluded from the analysis.

\section{Clinical characteristics and non-adherence}

Out of all patients, $40.3 \%(\mathrm{n}=108), 32.5 \% \quad(\mathrm{n}=87)$ and $27.2 \%(n=73)$ were diagnosed with smear positive, smear negative and extra pulmonary TB, respectively. At baseline, 3.7\% $(\mathrm{n}=10)$ patients were diagnosed with HIV, and $7.1 \%(\mathrm{n}=19)$ with other comorbidities. At baseline $9.7 \%$ $(\mathrm{n}=26)$ were non-adherent to TB medication. At 2 and
6 months of assessment, $26.1 \%(n=70)$ and $27.6 \%(n=74)$ missed at least one dose of their medications, respectively.

The prevalence of non-adherence among patients with substance use disorder was $16.4 \% \quad(n=22), 41.7 \% \quad(n=48)$ and $45.7 \%(\mathrm{n}=59)$ at baseline, first and second follow-up, respectively (see table 2 ).

\section{Effect of substance use disorder on the adherence to anti-TB medications}

The intercept only model (model 0) showed a significant decrease in the percentage of adherence over time $(\mathrm{BIC}=642.5)$. Adding alcohol and khat use disorders (model 1) improved model fit $(\mathrm{BIC}=627.6)$ : patients with khat use disorder had a significantly higher probability of non-adherence over time ( $\mathrm{OR}=4.2,95 \%$ CI 2.1 to 8.6). The odds of non-adherence among patients with AUD was 3.3 times that of patients free of AUDs $(\mathrm{OR}=3.3,95 \%$ CI 1.6 to 6.6 ). Adding covariates did not substantially change this association $(\mathrm{OR}=2.8,95 \% \mathrm{CI} 2.0$ to 3.8$)$ and further improved model fit $(\mathrm{BIC}=642.2)$. In the final model, khat use disorder ( $\mathrm{aOR}=3.8,95 \%$ CI 1.8 to 8.0 ), or AUD $(\mathrm{aOR}=3.2,95 \%$ CI 1.6 to 6.6$)$, being educated $(\mathrm{aOR}=4.4$, 95\% CI 1.7 to 11.3 ), and being merchant (aOR=6.1, 95\% CI 1.2 to 30.8) were associated with decreasing adherence (see table 3). Patients with khat use disorder were 3.8 times more likely to be non-adherent to anti-TB medications than patients without khat use disorder. Also, participants whose occupation was merchant were 6.1 times more likely to be non-adherent to anti-TB medications compared with daily labourers.

\section{DISCUSSION}

This study conducted in patients undergoing standardised treatment for TB in Southwest Ethiopia revealed three important findings: (1) adherence to medication decreased over the course of treatment; (2) substance use disorders, particularly khat and alcohol contributed to this non-adherence and (3) this association was independent of other factors such as education, social support and occupation.

It is alarming that adherence to $\mathrm{TB}$ medication decreased over the course of treatment, as already shown by studies done in South Ethiopia, ${ }^{52}$ Northwest Ethiopia $^{9}$ and Addis Ababa, ${ }^{53}$ Ethiopia. Possible reasons for non-compliance are distance from the health institution that dispenses medications, ${ }^{13}{ }^{52}$ lack of knowledge about $\mathrm{TB},{ }^{952}$ psychological distress, ${ }^{53}$ being busy with work ${ }^{9}$ and alcohol intake. ${ }^{51}$ To solve the problem related to adherence, Ethiopian health authorities have reinforced their efforts to implement DOT programmes throughout the whole treatment and all over the country starting from initiation to completion of treatment. ${ }^{12}$

In this study, the prevalence of non-adherence to anti-TB medication in the first month of treatment was $9.7 \%$ which is in line with a systematic review that found $10.0 \%$ of non-adherence in the Amhara region. ${ }^{13} 54$ The proportion of non-adherence to anti-TB medications 
Table 1 Sociodemographic characteristics and substance use disorder among a cohort of patients on antituberculosis treatment in Southwest Ethiopia, 2017/2018 ( $n=268)$

\begin{tabular}{|c|c|c|c|c|c|}
\hline \multirow[b]{2}{*}{ Variables } & & \multirow[b]{2}{*}{ Total (\%) } & \multicolumn{3}{|c|}{ Substance use disorder } \\
\hline & & & $\begin{array}{l}\text { Baseline } \\
\text { N (\%) }\end{array}$ & $\begin{array}{l}\text { First follow-up } \\
\mathrm{N}(\%)\end{array}$ & $\begin{array}{l}\text { Second follow-up } \\
\mathrm{N}(\%)\end{array}$ \\
\hline \multirow[t]{2}{*}{ Gender } & Female & 39.9 & $40(37.4)$ & $35(32.7)$ & 45 (42.1) \\
\hline & Male & 60.1 & $94(58.4)$ & $80(49.7)$ & $84(52.2)$ \\
\hline \multirow[t]{5}{*}{ Age } & $18-24$ & 34.7 & $42(45.2)$ & $31(33.3)$ & $38(40.9)$ \\
\hline & $25-34$ & 32.5 & $35(40.2)$ & $34(39.1)$ & $35(40.2)$ \\
\hline & $35-44$ & 13.4 & $23(63.9)$ & $20(55.6)$ & $22(61.1)$ \\
\hline & $45-54$ & 10.1 & $17(63.0)$ & $16(59.3)$ & $18(66.7)$ \\
\hline & $55-64$ & 9.3 & $17(68.0)$ & $14(56.0)$ & $16(64.0)$ \\
\hline \multirow[t]{4}{*}{ Occupation } & Merchant & 10.8 & $23(79.3)$ & $19(65.5)$ & $20(69.0)$ \\
\hline & Farmer & 34.3 & $57(62.0)$ & $51(55.4)$ & 57 (62.0) \\
\hline & Government employee & 39.2 & 37 (35.2) & $29(27.6)$ & $33(31.4)$ \\
\hline & Daily labourer & 15.7 & $17(40.5)$ & $16(38.1)$ & $19(45.2)$ \\
\hline \multirow[t]{2}{*}{ Education } & No formal education & 63.1 & $68(40.2)$ & $59(34.9)$ & $62(36.7)$ \\
\hline & Literate & 36.9 & $66(66.7)$ & $56(56.6)$ & $67(67.7)$ \\
\hline \multirow[t]{2}{*}{ Annual income in birr } & $<14568$ & 76.9 & $108(52.4)$ & $92(44.7)$ & $104(50.5)$ \\
\hline & $\geq 14568$ & 14.9 & $16(40.0)$ & $17(42.5)$ & $18(45.0)$ \\
\hline \multirow[t]{3}{*}{ Marital } & Single & 36.2 & $85(54.1)$ & $76(48.4)$ & $87(55.4)$ \\
\hline & Married & 58.6 & 39 (40.2) & $32(33.0)$ & $34(35.1)$ \\
\hline & Divorced/widowed & 5.2 & $10(71.4)$ & $7(50.0)$ & $8(57.1)$ \\
\hline \multirow[t]{3}{*}{ Religion } & Orthodox & 30.6 & $43(52.4)$ & 27 (32.9) & $43(52.4)$ \\
\hline & Muslim & 61.6 & 89 (53.9) & $86(52.1)$ & $82(49.7)$ \\
\hline & Protestant/others & 7.8 & $2(9.5)$ & $2(9.5)$ & $4(19.0)$ \\
\hline \multirow[t]{3}{*}{ Ethnicity } & Amhara & 22.0 & $27(45.8)$ & $17(28.8)$ & $29(49.2)$ \\
\hline & Oromo & 61.6 & $83(50.3)$ & $82(49.7)$ & 79 (47.9) \\
\hline & Tigre/Gurage & 16.4 & $24(54.5)$ & $16(36.4)$ & $21(47.7)$ \\
\hline \multirow[t]{2}{*}{ Family size } & Less than five & 67.5 & 89 (49.2) & $76(42.0)$ & 89 (49.2) \\
\hline & Five or greater & 32.5 & $45(51.7)$ & $39(44.8)$ & $40(46.0)$ \\
\hline \multirow[t]{2}{*}{ Residence } & Rural & 47.4 & $72(56.7)$ & $59(46.5)$ & $68(53.5)$ \\
\hline & Urban & 52.6 & $62(44.0)$ & $56(39.7)$ & $61(43.3)$ \\
\hline \multirow[t]{3}{*}{ Type of tuberculosis } & Smear positive & 40.3 & $54(50.0)$ & $43(39.8)$ & $46(42.6)$ \\
\hline & Smear negative & 32.5 & $43(49.4)$ & $39(44.8)$ & $46(52.9)$ \\
\hline & Extra pulmonary & 27.2 & $37(50.7)$ & $33(45.2)$ & $37(50.7)$ \\
\hline
\end{tabular}

during the first $(26.1 \%)$ and second $(27.6 \%)$ follow-up was slightly higher than findings from South Ethiopia $(24.5 \%),{ }^{52}$ Northwest Ethiopia $(21.2 \%)^{9}$ and Addis Ababa $(19.5 \%){ }^{53}$ This might be explained by the high proportion of persons with a substance use disorder in our study, in which we deliberately oversampled persons with substance use disorder (SUD) to maximise power. The discrepancy may be also due to patients in our study were using substances whereas in the systematic review there was no data regarding substance use.

In this study, the prevalence of non-adherence among patients with substance use disorder at baseline, first and second follow-up was $16.4 \%, 41.7 \%$ and $45.7 \%$, respectively. This is in line with a study from the USA $(39 \%) .{ }^{95556}$

Moreover, this study provides the evidence that substance use disorders have a significant negative effect on adherence to anti-TB medications among patients with $\mathrm{TB}$, which supports earlier findings from previous studies that found AUD, tobacco dependence and illicit drug use have a negative impact on adherence in Uzbekistan, Spain and Morocco. ${ }^{57-59}$ This is also comparable with retrospective studies conducted in Russia and New York which found that AUD and drug addiction were significantly associated with non-adherence to anti-TB medications. ${ }^{89}$ Likewise, the finding of this study is in line with 
Table 2 Various characteristics by adherence to antituberculosis (anti-TB) medications at the three time point assessments among patients with TB in Southwest Ethiopia 2017/2018 ( $n=268)$

\begin{tabular}{|c|c|c|c|c|c|c|c|}
\hline \multirow[b]{2}{*}{ Variables } & & \multicolumn{2}{|c|}{$\begin{array}{l}\text { Adherence to anti-TB at } \\
\text { baseline }\end{array}$} & \multicolumn{2}{|c|}{$\begin{array}{l}\text { Adherence to anti-TB at first } \\
\text { follow-up }\end{array}$} & \multicolumn{2}{|c|}{$\begin{array}{l}\text { Adherence to anti-TB at } \\
\text { second follow-up }\end{array}$} \\
\hline & & $\begin{array}{l}\text { Adherent } \\
\text { N (\%) }\end{array}$ & $\begin{array}{l}\text { Non-adherent } \\
\text { N (\%) }\end{array}$ & $\begin{array}{l}\text { Adherent } \\
\text { N (\%) }\end{array}$ & $\begin{array}{l}\text { Non-adherent } \\
\mathrm{N}(\%)\end{array}$ & $\begin{array}{l}\text { Adherent } \\
\mathrm{N}(\%)\end{array}$ & $\begin{array}{l}\text { Non-adherent } \\
\text { N (\%) }\end{array}$ \\
\hline \multirow{2}{*}{$\begin{array}{l}\text { Substance } \\
\text { use disorder }\end{array}$} & No & $130(97.0)$ & $4(3.0)$ & $131(85.6)$ & $22(14.4)$ & 124 (89.2) & 15 (10.8) \\
\hline & Yes & $112(83.6)$ & $22(16.4)$ & 67 (58.3) & $48(41.7)$ & $70(54.3)$ & $59(45.7)$ \\
\hline \multirow[t]{2}{*}{ Gender } & Male & $143(88.8)$ & $18(11.2)$ & $112(69.6)$ & $49(30.4)$ & 83 (77.6) & $24(22.4)$ \\
\hline & Female & 99 (92.5) & $8(7.5)$ & $86(80.4)$ & 21 (19.6) & $111(68.9)$ & $50(31.1)$ \\
\hline \multirow[t]{5}{*}{ Age } & $18-24$ & 88 (94.6) & $5(5.4)$ & 72 (77.3) & $21(22.7)$ & 69 (74.2) & $24(25.8)$ \\
\hline & $25-34$ & 79 (90.8) & $8(9.2)$ & $64(73.7)$ & $23(26.3)$ & $67(77.0)$ & $20(23.0)$ \\
\hline & $35-44$ & $28(77.8)$ & $8(22.2)$ & $24(66.7)$ & 12 (33.3) & 23 (63.9) & $13(36.1)$ \\
\hline & $45-54$ & 24 (88.9) & $3(11.1)$ & $21(77.8)$ & $6(22.2)$ & $19(70.4)$ & 8 (29.6) \\
\hline & $55-64$ & $23(92.0)$ & $2(8.0)$ & 17 (68.0) & $8(32.0)$ & $16(64.0)$ & $9(36.0)$ \\
\hline \multirow[t]{4}{*}{ Occupation } & Merchant & $22(75.9)$ & $7(24.1)$ & 17 (58.6) & $12(41.4)$ & $14(48.3)$ & $15(51.7)$ \\
\hline & Farmer & 79 (85.9) & $23(14.1)$ & $66(71.7)$ & $26(28.3)$ & $64(69.6)$ & $28(30.4)$ \\
\hline & $\begin{array}{l}\text { Government } \\
\text { employee }\end{array}$ & $21(95.5)$ & $1(4.5)$ & 79 (75.2) & $26(24.8)$ & $82(78.1)$ & 23 (21.9) \\
\hline & Daily labourer & 41 (97.6) & $1(2.4)$ & $36(85.0)$ & $6(14.3)$ & $34(81.0)$ & $8(19.0)$ \\
\hline \multirow[t]{3}{*}{ Education } & $\begin{array}{l}\text { No formal } \\
\text { education }\end{array}$ & 165 (97.6) & $4(2.4)$ & $145(85.8)$ & $24(14.2)$ & 139 (82.2) & $30(17.8)$ \\
\hline & Literate & 77 (77.8) & $22(22.2)$ & $53(53.5)$ & $46(46.5)$ & $55(55.6)$ & $44(44.4)$ \\
\hline & Tertiary & $20(71.4)$ & $8(28.6)$ & $8(28.6)$ & $20(71.4)$ & $10(35.7)$ & $18(64.3)$ \\
\hline \multirow{2}{*}{$\begin{array}{l}\text { Annual } \\
\text { income in birr }\end{array}$} & $<14568$ & $185(89.8)$ & $21(10.2)$ & $154(74.8)$ & $52(25.2)$ & 149 (72.3) & $57(27.7)$ \\
\hline & $\geq 14568$ & 37 (92.5) & $3(7.5)$ & $30(75.0)$ & $10(25.0)$ & 31 (77.5) & $9(22.5)$ \\
\hline \multirow{3}{*}{$\begin{array}{l}\text { Food } \\
\text { insecurity }\end{array}$} & No & 129 (94.9) & $7(5.1)$ & $105(72.4)$ & $40(27.6)$ & $118(72.8)$ & $44(27.2)$ \\
\hline & $\begin{array}{l}\text { Middle/ } \\
\text { moderate }\end{array}$ & $46(80.7)$ & 11 (19.3) & $29(70.0)$ & $12(29.3)$ & $26(60.5)$ & 17 (39.5) \\
\hline & Severe & 67 (89.3) & $8(10.7)$ & $64(78.0)$ & $18(22.0)$ & $50(79.4)$ & 13 (20.6) \\
\hline \multirow[t]{3}{*}{ Marital status } & Single & $92(94.8)$ & $5(5.2)$ & $109(69.4$ & $48(30.6)$ & $80(82.5)$ & $17(17.5)$ \\
\hline & Married & 140 (89.2) & $17(10.8)$ & $80(85.8)$ & 17 (17.2) & $104(66.2)$ & 53 (33.8) \\
\hline & $\begin{array}{l}\text { Divorced/ } \\
\text { widowed }\end{array}$ & $10(71.4)$ & $4(28.6)$ & $9(64.6)$ & $5(37.4)$ & $10(71.4)$ & $4(28.6)$ \\
\hline \multirow[t]{3}{*}{ Religion } & Orthodox & $74(90.2)$ & $8(9.8)$ & $63(76.8)$ & $19(23.2)$ & $61(74.4)$ & $21(25.6)$ \\
\hline & Muslim & $147(89.7)$ & $18(10.3)$ & $118(71.5)$ & $47(28.5)$ & $114(69.1)$ & $51(39.9)$ \\
\hline & $\begin{array}{l}\text { Protestant and } \\
\text { others }\end{array}$ & 20 (95.2) & $1(4.8)$ & 17 (81.0) & $4(19.0)$ & $19(90.5)$ & $2(9.5)$ \\
\hline \multirow[t]{3}{*}{ Ethnicity } & Amhara & $53(89.8)$ & $6(10.2)$ & $49(83.1)$ & 10 (16.9) & $48(81.4)$ & $11(18.6)$ \\
\hline & Oromo & 160 (90.9) & $16(9.1)$ & $119(72.1)$ & $46(27.9)$ & $119(72.1)$ & $46(27.9)$ \\
\hline & Tigre/Gurage & 29 (87.9) & $4(12.1)$ & $30(68.2)$ & 14 (31.8) & 27 (61.4) & 17 (38.6) \\
\hline \multirow[t]{2}{*}{ Family size } & Less than five & 165 (91.2) & $16(8.8)$ & 132 (72.9) & $49(27.1)$ & $137(75.7)$ & $44(24.3)$ \\
\hline & Five or greater & 77 (88.5) & $10(11.5)$ & 66 (75.9) & $21(24.1)$ & $57(64.5)$ & $30(34.5)$ \\
\hline \multirow[t]{2}{*}{ Residence } & Rural & $113(89.0)$ & $14(11.0)$ & $94(74.0)$ & $33(26.0)$ & 93 (73.2) & $34(26.8)$ \\
\hline & Urban & $129(91.5)$ & $12(8.5)$ & $104(73.0)$ & 37 (26.2) & 101 (71.6) & $40(28.4)$ \\
\hline \multirow[t]{3}{*}{ Type of TB } & Smear positive & 95 (91.9) & $13(8.1)$ & $80(74.1)$ & 28 (25.9) & 78 (72.2) & $30(27.8)$ \\
\hline & Smear negative & $81(9.1)$ & $6(6.9)$ & 66 (75.9) & $21(24.1)$ & 64 (73.6) & $23(26.4)$ \\
\hline & $\begin{array}{l}\text { Extra } \\
\text { pulmonary }\end{array}$ & $66(90.4)$ & $7(9.6)$ & $52(71.2)$ & $21(28.8)$ & $52(71.2)$ & $21(28.8)$ \\
\hline
\end{tabular}


Table 2 Continued

\begin{tabular}{|c|c|c|c|c|c|c|c|}
\hline \multirow[b]{2}{*}{ Variables } & & \multicolumn{2}{|c|}{$\begin{array}{l}\text { Adherence to anti-TB at } \\
\text { baseline }\end{array}$} & \multicolumn{2}{|c|}{$\begin{array}{l}\text { Adherence to anti-TB at first } \\
\text { follow-up }\end{array}$} & \multicolumn{2}{|c|}{$\begin{array}{l}\text { Adherence to anti-TB at } \\
\text { second follow-up }\end{array}$} \\
\hline & & $\begin{array}{l}\text { Adherent } \\
\mathrm{N}(\%)\end{array}$ & $\begin{array}{l}\text { Non-adherent } \\
\text { N (\%) }\end{array}$ & $\begin{array}{l}\text { Adherent } \\
\mathrm{N}(\%)\end{array}$ & $\begin{array}{l}\text { Non-adherent } \\
\text { N (\%) }\end{array}$ & $\begin{array}{l}\text { Adherent } \\
\text { N (\%) }\end{array}$ & $\begin{array}{l}\text { Non-adherent } \\
\text { N (\%) }\end{array}$ \\
\hline \multirow[t]{2}{*}{ HIV } & Seronegative & $233(90.3)$ & $25(9.7)$ & $190(74.2)$ & $66(25.8)$ & $183(73.5)$ & $66(26.5)$ \\
\hline & Seropositive & $9(90.0)$ & $1(10.0)$ & $8(66.7)$ & $4(33.3)$ & $11(57.9)$ & $8(42.1)$ \\
\hline \multirow[t]{3}{*}{ Social support } & Poor & 83 (89.2) & $10(10.8)$ & 83 (74.8) & $28(25.2)$ & $96(68.6)$ & $44(34.1)$ \\
\hline & Moderate & $101(89.4)$ & $12(10.6)$ & $68(80.0)$ & $17(20.0)$ & $58(78.4)$ & $16(21.6)$ \\
\hline & Good & 58 (93.5) & $4(6.5)$ & 47 (65.3) & $25(34.7)$ & $40(74.1)$ & $14(25.9)$ \\
\hline
\end{tabular}

studies conducted in different parts of Ethiopia which found khat, alcohol and tobacco are the main factors for non-adherence to anti-TB medications. ${ }^{95660}$ In our study, patients with substance use disorder were more than two times more likely not to follow their medication plan than patients without substance use disorders. This finding is in line with the finding of a study conducted in the USA that found the risk of missing a DOT appointment was 2.6 times higher among patients with substance use disorder than in patients without drug consumption. ${ }^{55}$

In our study, khat use disorder turned out to be the most stringent factor that decreased adherence. This confirms earlier findings from Yemen ${ }^{35}$ and Ethiopia. ${ }^{1460}$ A plausible explanation is that khat chewing disrupts night sleep $^{61}$ causing patients to oversleep which may lead to missing of the DOT appointments at the health facility.

Table 3 Predictors of non-adherence to antituberculosis (anti-TB) medications among patients with TB in Southwest Ethiopia $2017 / 2018(n=268)$

\begin{tabular}{|c|c|c|c|}
\hline Model 0 (intercept only) & $\begin{array}{l}\text { Model } 1 \text { (khat and alcohol } \\
\text { including age and gender) }\end{array}$ & Full model & \\
\hline $95 \% \mathrm{Cl}$ & $95 \% \mathrm{Cl}$ & $\begin{array}{l}\text { Adjusted } \\
\text { odds ratio } \\
\text { (aOR) }\end{array}$ & $95 \% \mathrm{Cl}$ \\
\hline
\end{tabular}

\begin{tabular}{|c|c|c|c|c|c|c|c|}
\hline Variables & & OR & $95 \% \mathrm{Cl}$ & OR & $95 \% \mathrm{Cl}$ & (aOR) & $95 \% \mathrm{Cl}$ \\
\hline \multirow[t]{2}{*}{ Khat UD } & No & Reference & & & & & \\
\hline & Yes & - & - & 4.2 & 2.1 to 8.6 & 3.8 & 1.8 to 8.0 \\
\hline \multirow[t]{2}{*}{ AUDs } & No & Reference & & & & & \\
\hline & Yes & - & - & 3.3 & 1.6 to 6.6 & 3.2 & 1.6 to 6.6 \\
\hline \multirow[t]{5}{*}{ Age } & $18-24$ & Reference & & & & & \\
\hline & $25-34$ & - & - & 1.2 & 0.4 to 3.2 & - & - \\
\hline & $35-44$ & - & - & 1.8 & 0.5 to 6.4 & - & - \\
\hline & $45-54$ & - & - & 0.9 & 0.2 to 4.0 & - & - \\
\hline & $\geq 55$ & - & - & 1.2 & 0.3 to 5.1 & - & - \\
\hline \multirow[t]{2}{*}{ Gender } & Female & Reference & & & & & \\
\hline & Male & - & - & 1.6 & 0.7 to 3.6 & - & - \\
\hline \multirow[t]{2}{*}{ Education } & No formal education & Reference & & & & & \\
\hline & Read and write/literate & - & - & - & - & 4.4 & 1.7 to 11.3 \\
\hline \multirow[t]{3}{*}{ Social support } & Good & Reference & & & & & \\
\hline & Moderate & - & - & - & - & 0.5 & 0.2 to 1.2 \\
\hline & Poor & - & - & - & - & 0.8 & 0.3 to 1.9 \\
\hline \multirow[t]{4}{*}{ Occupation } & Daily labourer & Reference & & & & & \\
\hline & Farmer & - & - & - & - & 2.1 & 0.5 to 8.0 \\
\hline & Government employee & - & - & - & - & 2.1 & 0.6 to 8.0 \\
\hline & Merchant & - & - & - & - & 6.1 & 1.2 to 30.8 \\
\hline Time T2 & & 2.7 & 2.0 to 3.6 & 2.7 & 2.0 to 3.6 & 2.8 & 2.0 to 3.8 \\
\hline $\mathrm{BIC}$ & & 642.5 & & 672.6 & & 642.2 & \\
\hline
\end{tabular}


Another reason may be that khat is common substance in Ethiopia, and therefore less attention is paid to its use. Since little is known about the effect of khat on patients with $\mathrm{TB},{ }^{14}$ it may be considered as part of a normal social interaction. $^{35}$

A higher level of education was associated with nonadherence to anti-TB medications in our study. This result confirms the findings from Yemen that found more educated patients were $19 \%$ times less likely to be adherent to their medication. ${ }^{35}$ Also, a study from Ethiopia showed that attending primary education was associated with non-adherence to anti-TB medications. ${ }^{60}$ Our findings are contrary to previous studies which have suggested that lower or no formal education decreases adherence to TB medication. ${ }^{1362}$ Our finding seems counterintuitive. However, our results are likely to be related to findings from a study indicating that persons with higher educational attainment might be reluctant to accept DOTS regimes. ${ }^{63}$ Daily visits to the health facility have been reported as time consuming and probably stigmatising for patients with a job. ${ }^{64}$ In this study, being merchant was associated with poor adherence to anti-TB medications. This might be due to patients miss their medications because of busy working schedule, but this needs further investigation.

\section{Limitations}

This study has some limitations. Due to social desirability, patients might minimise reporting of the amount and frequency of substance they were using. The tools used for alcohol and khat use disorder are not gold-standard diagnostic for the respective disorders. Also, measuring adherence based on pills count may not reflect the real adherence situation since some patients might not bring all leftover medications during the follow-up. Likewise, follow-up and data collections have been carried out by health professionals working in the respective TB clinics which might have biased their assessment of adherence. However, overestimating adherence may have biased our results towards a null effect and led to underestimating the effect of substance use disorders, so we are confident that our estimates are conservative. The participation of district TB focal persons and other health professionals in the supervision of data collection might have also introduced bias.

Furthermore, hospitalised patients, patients on re-treatment and patients with MDR-TB were not included in this study, so that the results cannot be generalised for these patients. However, patients with MDR-TB are under special treatment and surveillance so that including this group of patients might have biased the results. Finally, we did not assess the reasons for non-adherence. This should be part of a separate study going more into the details of the situation of persons with khat and alcohol problems.

\section{Strengths}

The specific strengths of this study are the prospective cohort design, longitudinal data collection, including patients from urban and rural health institutions, intensive training given for data collectors, multi-centre data collection and the use of standardised instruments to assess exposure, outcomes and explanatory variables.

\section{CONCLUSIONS}

Substance use disorders predict greater likelihood of anti-TB medication non-adherence among patients with TB. Also, khat and AUDs were the main risk factors for anti-TB medication adherence. This finding implies the importance of integrating substance use disorders screening and treatment into the existing TB services to reduce the effect of substances on treatment outcomes including adherence.

\section{Author affiliations}

${ }^{1}$ Department of Psychiatry, Medical Faculty, Jimma University, Jimma, Ethiopia ${ }^{2}$ Center for International Health, Ludwig Maxmilians University, Munich, Germany ${ }^{3}$ Department of Psychiatry, St. Paul's Hospital Millennium Medical College, Addis Ababa, Ethiopia

${ }^{4}$ Department of Psychiatry and Psychotherapy, LMU Munich, Munich, Germany ${ }^{5}$ Institute of Psychiatric Phenomics and Genomics (IPPG), University Hospital, LMU Munich, Munich, Germany

${ }^{6}$ Department of Forensic Psychiatry, Isar Amper Klinikum, Munich, Germany ${ }^{7}$ Institute for Medical Information Processing, Biometry and Epidemiology,Ludwig Maximilians University Muenchen, Munich, Germany

${ }^{8}$ German Center for Vertigo and Balance Disorders, University Hospital LMU Muenchen, Munich, Germany

Acknowledgements We are grateful to the study participants for sacrificing their time to participate in the study. Our gratitude is extended to Jimma University for funding the project. We are also grateful to IPPG for funding part of the project. Our gratitude also extends to Dr Michael Odenwald, who contributed money from his pocket to support the project.

Contributors MS contributed to the conceptualisation, design, statistical analysis and manuscript preparation. MT, KA, WK, ET, YY, RS and EG contributed to the design, analysis and review of the manuscript.

Funding The study was funded by Jimma University Institute of Health with the grant number of IHRPGC 1095/2017, Institute of Psychiatric Phenomics and Genomics (IPPG) with the grant number of 15106202/2018 and individual throughout data collection. The funders had no role in this study including interpretation and preparation of the manuscript.

\section{Competing interests None declared.}

Patient and public involvement Patients and/or the public were not involved in the design, or conduct, or reporting, or dissemination plans of this research.

Patient consent for publication Not required.

Ethics approval Ethical clearance was obtained from the Ethical Review Board of Jimma University (IHRPGC1095/2017) and LMU (Nr: 18-017). The study was discussed in detail and written informed consent was obtained from each participant. The anonymity of the study participants was kept at all stages of data processing and write-up of the manuscript. Patients who had alcohol and khat use disorder were advised to contact a mental health professional for further evaluation and treatment.

Provenance and peer review Not commissioned; externally peer reviewed.

Data availability statement Data are available upon reasonable request. Data may be obtained from a third party and are not publicly available. All data relevant to the study are included in the article or uploaded as supplementary information. It will be available upon official request from interested individuals or organisations.

Open access This is an open access article distributed in accordance with the Creative Commons Attribution Non Commercial (CC BY-NC 4.0) license, which permits others to distribute, remix, adapt, build upon this work non-commercially, and license their derivative works on different terms, provided the original work is 
properly cited, appropriate credit is given, any changes made indicated, and the use is non-commercial. See: http://creativecommons.org/licenses/by-nc/4.0/.

\section{ORCID iDs}

Matiwos Soboka http://orcid.org/0000-0003-2820-0947

Yimenu Yitayih http://orcid.org/0000-0002-0300-394X

\section{REFERENCES}

1 World Health Organization. Global tuberculosis report 2018. Licence: CC BY-NC-SA 3.0 IGO. Geneva: World Health Organization, 2018. https://www.who.int/tb/publications/global report/en/

2 Grobusch MP, Kapata N. Global burden of tuberculosis: where we are and what to do. Lancet Infect Dis 2018;18:1291-3.

3 Patel V, Chisholm D, Dua T, et al. Neurological, and substance use disorders: disease control priorities, third edition (Volume 4). Washington (DC): The International Bank for Reconstruction and Development / The World Bank, 2016.

4 Floyd K, Glaziou P, Zumla A, et al. The global tuberculosis epidemic and progress in care, prevention, and research: an overview in year 3 of the end TB era. Lancet Respir Med 2018;6:299-314.

5 World Health Organization. Global tuberculosis report 2016. Geneva: World Health Organization, 2016. https://apps.who.int/medicinedocs/ en/d/Js23098en/

6 Dodor EA. Tuberculosis treatment default at the communicable diseases unit of Effia-Nkwanta regional Hospital: a 2-year experience. Int J Tuberc Lung Dis 2004;8:1337-41.

7 World Health Organization. Global tuberculosis report 2013. Geneva: World Health Organization, 2013. http://apps.who.int/medicinedocs/ en/m/abstract/Js21534en/

8 Gelmanova IY, Keshavjee S, Golubchikova VT, et al. Barriers to successful tuberculosis treatment in Tomsk, Russian Federation: non-adherence, default and the acquisition of multidrug resistance. Bull World Health Organ 2007;85:703-11.

9 Mekonnen HS, Azagew AW. Non-adherence to anti-tuberculosis treatment, reasons and associated factors among TB patients attending at Gondar town health centers, Northwest Ethiopia. BMC Res Notes 2018;11:691.

10 Mohd Shariff N, Shah SA, Kamaludin F. Predictors of death among drug-resistant tuberculosis patients in Kuala Lumpur, Malaysia: a retrospective cohort study from 2009 to 2013. J Glob Antimicrob Resist 2016;6:102-7.

11 Waitt CJ, Squire SB. A systematic review of risk factors for death in adults during and after tuberculosis treatment. Int J Tuberc Lung Dis 2011;15:871-85

12 Federal Democratic Republic of Ethiopia Ministry of Health. Guidelines for clinical and programmatic management of TB, leprosy and TB/HIV in Ethiopia fifth edition, 2012. Available: https://www. mhinnovation.net/sites/default/files/downloads/innovation/reports/ ETHIOPIA-NATIONAL-MENTAL-HEALTH-STRATEGY-2012-1.pdf [Accessed 13 Apr 2020].

13 Zegeye A, Dessie G, Wagnew F, et al. Prevalence and determinants of anti-tuberculosis treatment non-adherence in Ethiopia: a systematic review and meta-analysis. PLoS One 2019;14:e0210422.

14 Ambaw F, Mayston R, Hanlon C, et al. Untreated depression and tuberculosis treatment outcomes, quality of life and disability, Ethiopia. Bull World Health Organ 2018;96:243-55.

15 Pelissari DM, Diaz-Quijano FA. Impact of alcohol disorder and the use of illicit drugs on tuberculosis treatment outcomes: a retrospective cohort study. Arch Public Health 2018;76:45.

16 Silva MR, Pereira JC, Costa RR, et al. Drug addiction and alcoholism as predictors for tuberculosis treatment default in Brazil: a prospective cohort study. Epidemiol Infect 2017:145:3516-24.

17 Deiss RG, Rodwell TC, Garfein RS. Tuberculosis and illicit drug use: review and update. Clin Infect Dis 2009;48:72-82.

18 Oeltmann JE, Kammerer JS, Pevzner ES, et al. Tuberculosis and substance abuse in the United States, 1997-2006. Arch Intern Med 2009;169:189-97.

19 O'Connell R, Chishinga N, Kinyanda E, et al. Prevalence and correlates of alcohol dependence disorder among TB and HIV infected patients in Zambia. PLoS One 2013;8:e74406.

20 Christensen A-SH, Roed C, Andersen PH, et al. Long-Term mortality in patients with pulmonary and extrapulmonary tuberculosis: a Danish nationwide cohort study. Clin Epidemiol 2014;6:405-21.

21 Fleming MF, Krupitsky E, Tsoy M, et al. Alcohol and drug use disorders, HIV status and drug resistance in a sample of Russian TB patients. Int J Tuberc Lung Dis 2006;10:565-70.

22 Skrahina A, Hurevich $\mathrm{H}$, Zalutskaya A, et al. Multidrug-Resistant tuberculosis in Belarus: the size of the problem and associated risk factors. Bull World Health Organ 2013;91:36-45.
23 Luqman W, Danowski TS. The use of khat (Catha edulis) in Yemen. social and medical observations. Ann Intern Med 1976;85:246-9.

24 Gebissa E. Khat in the horn of Africa: historical perspectives and current trends. J Ethnopharmacol 2010;132:607-14.

25 Dhaifalah I, Santavý J. Khat habit and its health effect. A natural amphetamine. Biomed Pap Med Fac Univ Palacky Olomouc Czech Repub 2004;148:11-15

26 Alfaifi H, Abdelwahab SI, Mohan S, et al. Catha edulis forsk. (Khat): evaluation of its antidepressant-like activity. Pharmacogn Mag 2017;13:S354-8.

27 Wolde D, Tadesse M, Abdella K, et al. Tuberculosis among Jimma university undergraduate students: first insight about the burden of tuberculosis in Ethiopia Universities-Cross-Sectional study. Int J Bacteriol 2017;2017:1-6.

28 Alemu YM, Awoke W, Wilder-Smith A. Determinants for tuberculosis in HIV-infected adults in Northwest Ethiopia: a multicentre casecontrol study. BMJ Open 2016;6:e009058.

29 Jaber AAS, Khan AH, Sulaiman SAS, et al. Role of sociodemographical factors on tuberculosis outcome in Yemen. Int $J$ Mycobacteriol 2016;5 Suppl 1:S20.

30 Legesse M, Ameni G, Mamo G, et al. Knowledge and perception of pulmonary tuberculosis in pastoral communities in the middle and lower Awash Valley of afar region, Ethiopia. BMC Public Health 2010;10:187.

31 Alvi A, Rizwan M, Sunosi RAL, et al. Does khat chewing increases the risk of Mycobacterium tuberculosis infection by macrophage immune modulation? Med Hypotheses 2014;82:667-9.

32 Jaber AAS, Khan AH, Syed Sulaiman SA, et al. Evaluation of healthrelated quality of life among tuberculosis patients in two cities in Yemen. PLoS One 2016;11:e0156258.

33 Jaber AAS, Khan AH, Sulaiman SAS. Evaluating treatment outcomes and durations among cases of smear-positive pulmonary tuberculosis in Yemen: a prospective follow-up study. J Pharm Policy Pract 2017;10:36.

34 Alvi A, Fatima N, Jerah AA, et al. Correlation between resistin, tuberculosis and khat addiction: a study from South Western Province of Saudi Arabia. PLoS One 2015;10:e0140245.

35 Anaam MS, Mohamed Ibrahim MI, Al Serouri AW, et al. Factors affecting patients' compliance to anti-tuberculosis treatment in Yemen. Journal of Pharmaceutical Health Services Research 2013;4:115-22.

36 Cox G, Rampes H. Adverse effects of khat: a review. Advances in Psychiatric Treatment 2003;9:456-63.

37 EPInfoTM. Available: https://www.openepi.com/SampleSize/ SSCohort.htm [Accessed 19 Aug 2019].

38 Babor TF, Higgins-Biddle JC, Saunders JB, et al. The alcohol use disorders identification test guidelines for use in primary care. Geneva: World Health Organization, 2001. https://apps.who.int/ iris/bitstream/handle/10665/67205/WHO_MSD_MSB 01.6a.pdf; jsessionid=B5D5F8F1F1B82FE622D04E8F02635F05? sequence $=1$

39 Babor TF, Higgins-Biddle JC, Saunders JB, et al. The alcohol use disorders identification test quidelines for use in primary care. Geneva: World Health Organization, 2001.

40 Soboka M, Tesfaye M, Feyissa GT, et al. Alcohol use disorders and associated factors among people living with HIV who are attending services in South West Ethiopia. BMC Res Notes 2014;7:828.

41 Mikami I, Akechi T, Kugaya A, et al. Screening for nicotine dependence among smoking-related cancer patients. Jpn J Cancer Res 1999;90:1071-5.

42 Duresso SW, Matthews AJ, Ferguson SG, et al. Is khat use disorder a valid diagnostic entity? Addiction 2016;111:1666-76.

43 salaryexplorer. Average salary in Ethiopia, 2019. Available: http:// www.salaryexplorer.com/salary-survey.php?loc=69\&loctype $=1$

44 EU. Instrument manual: Oslo-3 social support scale (OSS-3), 2006. Available: https://circabc.europa.eu/webdav/CircaBC/ESTAT/healthtf/ Library/ehis_wave_2/methodology_ehis/development/instruments/ Manual OSS 3.pdf

45 Duko B, Gebeyehu A, Ayano G. Prevalence and correlates of depression and anxiety among patients with tuberculosis at WolaitaSodo university hospital and Sodo health center, WolaitaSodo, South Ethiopia, cross sectional study. BMC Psychiatry 2015;15:214.

46 Coates JSA, Bilinsky P. Household food insecurity access scale (HFIAS) for measurement of food access: indicator guide (V.3. Washington, D.C: FHI 360/FANTA, 2007. http://www.fao.org/ fileadmin/user_upload/eufao-fsi4dm/doc-training/hfias.pdf

47 Tesfaye M, Kaestel P, Olsen MF, et al. Food insecurity, mental health and quality of life among people living with HIV commencing antiretroviral treatment in Ethiopia: a cross-sectional study. Health Qual Life Outcomes 2016;14:37. 
48 Maes KC, Hadley C, Tesfaye F, et al. Food insecurity among volunteer AIDS caregivers in Addis Ababa, Ethiopia was highly prevalent but buffered from the 2008 food crisis. J Nutr 2009;139:1758-64.

49 Greenland S, Pearl J, Robins JM. Causal diagrams for epidemiologic research. Epidemiology 1999;10:37-48.

50 Textor J, Hardt J, Knüppel S. DAGitty: a graphical tool for analyzing causal diagrams. Epidemiology 2011;22:745.

51 Shrier I, Platt RW. Reducing bias through directed acyclic graphs. BMC Med Res Methodol 2008;8:70.

52 Woimo TT, Yimer WK, Bati T, et al. The prevalence and factors associated for anti-tuberculosis treatment non-adherence among pulmonary tuberculosis patients in public health care facilities in South Ethiopia: a cross-sectional study. BMC Public Health 2017;17:269.

53 Tola HH, Garmaroudi G, Shojaeizadeh D, et al. The effect of psychosocial factors and patients' perception of tuberculosis treatment Non-Adherence in Addis Ababa, Ethiopia. Ethiop $J$ Health Sci 2017;27:447-58.

54 Adane AA, Alene KA, Koye DN, et al. Non-adherence to antituberculosis treatment and determinant factors among patients with tuberculosis in Northwest Ethiopia. PLoS One 2013;8:e78791.

55 Ricks PM, Hershow RC, Rahimian A, et al. A randomized trial comparing standard outcomes in two treatment models for substance users with tuberculosis. Int J Tuberc Lung Dis 2015;19:326-32.

56 Sahile Z, Yared A, Kaba M. Patients' experiences and perceptions on associates of TB treatment adherence: a qualitative study on dots service in public health centers in Addis Ababa, Ethiopia. BMC Public Health 2018;18:462.
57 Hasker E, Khodjikhanov M, Usarova S, et al. Default from tuberculosis treatment in Tashkent, Uzbekistan; who are these defaulters and why do they default? BMC Infect Dis 2008;8:97.

58 Caylà JA, Caminero JA, Rey R, et al. Current status of treatment completion and fatality among tuberculosis patients in Spain. Int $J$ Tuberc Lung Dis 2004;8:458-64.

59 Dooley KE, Lahlou O, Ghali I, et al. Risk factors for tuberculosis treatment failure, default, or relapse and outcomes of retreatment in Morocco. BMC Public Health 2011;11:40.

60 Tesfahuneygn G, Medhin G, Legesse M. Adherence to antituberculosis treatment and treatment outcomes among tuberculosis patients in Alamata district, northeast Ethiopia. BMC Res Notes 2015;8:503.

61 Adane K, Spigt M, Ferede S, et al. Half of pulmonary tuberculosis cases were left undiagnosed in prisons of the Tigray region of Ethiopia: implications for tuberculosis control. PLoS One 2016;11:e0149453

62 Fang X-H, Dan Y-L, Liu J, et al. Factors influencing completion of treatment among pulmonary tuberculosis patients. Patient Prefer Adherence 2019;13:491-6.

63 Kawatsu L, Uchimura K, Ohkado A, et al. A combination of quantitative and qualitative methods in investigating risk factors for lost to follow-up for tuberculosis treatment in Japan - Are physicians and nurses at a particular risk? PLoS One 2018;13:e0198075.

64 Gebreweld FH, Kifle MM, Gebremicheal FE, et al. Factors influencing adherence to tuberculosis treatment in Asmara, Eritrea: a qualitative study. J Health Popul Nutr 2018;37:1. 